\title{
Effects of Photoperiods on the Length and Number of Epidermal Cells in Runners of Strawberry Plants
}

\author{
Takashi Nishizawa* \\ Faculty of Agriculture, University of Tokyo, Tokyo 113
}

\begin{abstract}
Summary
Experiments were conducted to assess the importance of the length and the number of epidermal cells in regard to runner length in June-bearing strawberry plants (Fragaria $X$ ananassa, cv. Donner).

When the elongation rate of proximal internode (I-1) reached the highest rate, the distal internode ( $\mathrm{I}-2)$ started to elongate exponentially. The elongation pattern of each internode was represented by a single sigmoid curve. The cell division in I- 2 continued for about 5 days longer than that in $\mathrm{I}-1$.

I-1 and I-2 under a 16-hr day (LD) grew longer than did those which grew under a 9 $\mathrm{hr}$ day (SD). The increase in the internode length of $\mathrm{I}^{-1}$ was attributed to the increase in the epidermal cell length, whereas, the increase in the internode length of I-2 was attributed to the increase in the number of epidermal cells. The differences between I- 1 and I-2 of strawberry runners in photoperiodic response to the length and number of epidermal cells may be attributed to the difference of developmental stages in each internode at the onset of the photoperiodic treatments.

In photoperiodic response to the length and number of epidermal cells, there was a similarity between runners and petioles.
\end{abstract}

\section{Introduction}

Strawberry runners are two-noded stolons. After the basal or proximal internode elongates and terminates in a blind node, the distal one starts to elongate and terminates in a second node. Under favorable conditions, the second node initiates a daughter plant and/or develops one or more secondary runners. In herbaceous plants, the elongation of internodes shows some variation in growth patterns (Garrison, 1973; Fisher and French, 1976). However, the information is limited about the elongation of internodes in runners of strawberry plants. Guttridge (1970) revealed that the elongation of runners in strawberry plants was promoted under long-photoperiods, but inhibited under short-photoperiods. The elongation of an internode involves cell division and cell enlargement

Received for publication 13 October 1992. A part of this study was presented at the Spring Meetings of the Japanese Society for Horticultural Science, Tokyo, 1992.

* Present address: Faculty of Agriculture, Yamagata University, Tsuruoka, 997.
(Nishizawa and Hori, 1993). Therefore, the length and/or the number of internodal cells seem to be influenced by photoperiods.

The objectives of this study were to: 1) investigate the growth patterns including the changes in the length and the number of internodal cells of runners in strawberry plants; and 2) determine how photoperiods control these two functions.

\section{Materials and Methods}

In all experiments, June-bearing strawberry plants (Fragaria $\times$ ananassa, cv Donner) were planted in a potting mixture of soil : peat : vermiculite $(5: 3: 2, v / v / v)$. A slow-release fertilizer of $15 \mathrm{~N}: 6 \mathrm{P}: 12 \mathrm{~K}$ was added at $1.5 \mathrm{~g}$ per pot in Experiment $\mathrm{I}$, and at $1.0 \mathrm{~g}$ per pot in Experiments II and III. A single runner per plant was allowed to grow; the others were removed as soon as they emerged. Daughter plants which were formed at the apices of runners were not allowed to root. In Experiments II and III, the first leaf to emerge from the plant was designated as L1, and successively younger leaves were consecutively num- 
bered as L2, L3, L4, etc.

Experiment I. Elongation Patterns of the Internodes.

Plants were overwintered in a nursery at the Prefectural Agricultural Research Center of Miyagi. On 19 May 1988, 7 plants were potted in $18 \mathrm{~cm}$ diameter clay pots and transferred to a plastic film greenhouse at the university research field. On 7 June, they were transferred to a growth chamber maintained at $20^{\circ} \mathrm{C}$ under a naturalphotoperiod. The length of runners which formed in the leaf axil of the second leaf to emerge was measured daily for 20 days.

\section{Experiment II. Changes in the Length and Number of Internodal Cells.}

In September 1988, plants were potted in 30 $\mathrm{cm}$ diameter clay pots and overwintered outdoors. On 31 March 1989, they were transferred to an unheated greenhouse and allowed to produce runners. On 15 May, the daughter plants were potted in $12 \mathrm{~cm}$ diameter plastic pots. On 29 June, 25 uniform plants which had L7 as the youngest un. folding leaf were transferred to a growth chamber maintained at $20^{\circ} \mathrm{C}$ under a natural-photoperiod. The runners which formed in the leaf axil of L6 were collected and cut at the nodes into the proximal internode (I-1) and distal internode (I-2) (Fig. 1). The internodes which were shorter than 3 $\mathrm{cm}$ were divided into 10 sections of equal length, and then fixed in $3.5 \%$ glutaraldehyde in $0.25 \mathrm{M}$ phosphate buffer. The sections were then dehydrated in a graded ethanol series, embedded in Acrytron's resin (Mitsubishi Rayon Inc.), sliced longitudinally at 5 to $10 \mu \mathrm{m}$ thickness with a microtome. The sections were stained with $1 \%$ toluidine blue. The internodes which were longer than $3 \mathrm{~cm}$ were divided into 10 sections of equal

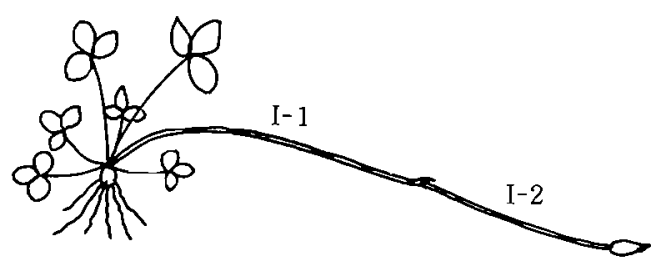

Fig. 1. Schematic diagram of a strawberry runner. The proximal internode and the distal internode were designated as I- 1 and $I-2$, respectively. length, and then fixed in a FAA solution consisting of formaldehyde: acetic acid: $50 \%$ ethanol $(5: 5: 90, \mathrm{v} / \mathrm{v} / \mathrm{v})$. The epidermal tissues were stripped off from the central portions of the sections and stained with $1 \%$ ruthenium red. The lengths of 15 epidermal cells on the central portion of each section were measured with a calibrated ocular micormeter. When the end of the walls of a cell was sloping, the length was measured to the midpoint of the slope as described by Guttridge and Thompson (1963). The number of epidermal cells per internode length (internodal cell number) was computed from the internode length divided by the mean epidermal cell length (internodal cell length) as reported previously in strawberry petioles (Guttridge and Thompson, 1963; Gosselink and Smith, 1967; Nishizawa, 1990, 1992).

\section{Experiment III. Effects of Photoperiods on the Length and Number of Internodal Cells and Petiolar Cells.}

Daughter plants from Experiments II were transferred to $12 \mathrm{~cm}$ diameter plastic pots on 10 June 1989. On 5 August, 20 uniform plants which had L9 as the youngest emerging leaf were divided into 2 groups. One group was transferred to a growth chamber maintained at $27^{\circ} / 20^{\circ} \mathrm{C}$ (day/night) under a 16-hr (LD) and the other to a 9-hr (SD) daylength. The growth chambers were illuminated for 9 hours from 7:30 to 16:30 with $40 \mathrm{~W}$ fluorescent lamps $\left(300 \mu \mathrm{mol} \mathrm{m}^{-2} \cdot \mathrm{s}^{-1}\right.$ photosynthetically active radiation). Plants under SD and LD were illuminated from $7: 30$ to $16: 30$ (9-hr, SD) and from 4:30 to 20:30 (16-hr, LD) with $10 \mathrm{~W}$ incandescent lamps $\left(5 \mu \mathrm{mol} \mathrm{m}^{-2}\right.$. $\left.s^{-1}\right)$

The first runner which formed and emerged in the leaf axil of $L 8$ was sampled 25 days after emergence. The internodal cell lengths of $\mathrm{I}-1$ and $\mathrm{I}-2$ were measured as described in Experiment II.

\section{Results}

\section{Experiment $I$.}

The growth curves of the internodes followed a single sigmoid curve. When the elongation rate of I-1 almost reached the highest rate, the exponential elongation of I-2 was initiated. When the elongation rate of $1-2$ approached maximum, the elongation of I-1 ceased. The rapid elongation of 
each internode lasted for approximately 10 days (Fig.2).

\section{Experiment $I I$.}

When I-1 reached about one third to half of the final length, the exponential elongation of I-2 was initiated. The elongation of internodal cells corresponded with the internode. However, the increase in the number of internodal cells ceased about 4 to
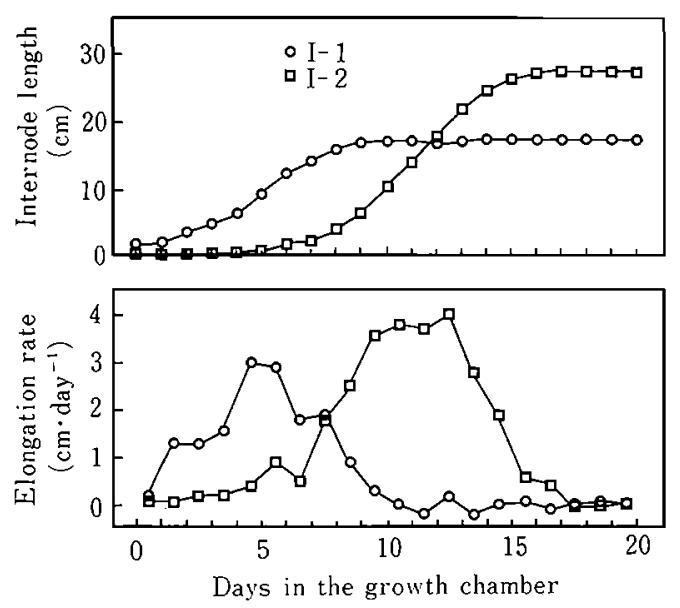

Fig. 2. Growth curves (upper) and elongation rates (lower) of internodes of strawberry runners at $20^{\circ} \mathrm{C}$ under natural photoperiod.
5 days earlier than the increase in internodal cell length. Cell division of internodal cells in I-1 ceased about 5 days earlier than it did in I-2 (Fig. 3).

\section{Experiment $I I I$.}

The internodal cell length of I-1 under LD was longer than that growing under SD in all segments except the most distal (10th level) one. In $I-2$, however, the internodal cells were equally long in all 10 segments (Fig. 4).

I- 1 and I- 2 were longer under $L D$ than under $\mathrm{SD}$. The internodal lengths of $\mathrm{I}-1$ under $\mathrm{LD}$ were $29.2 \%$ longer than those grown under SD. This increase is reflected by the internodal cell length which were $28.2 \%$ longer; the number of internodal cells under LD were $2.2 \%$ greater than under $\mathrm{SD}$ which was insignificant. In I-2, however, the $14.2 \%$ increase in the internode length under LD over that under SD is entirely accounted for by the greater number of internodal cells (15.0\%) and not to the internodal cell length (Table 1 ).

The petioles of L9, L10, and L11 under LD were $50.0,93.8$, and $98.9 \%$ longer, respectively, than those under SD. The increase in the petiole length of L9 under LD is mostly attributed to the $53.4 \%$ greater cell length. However, the greater
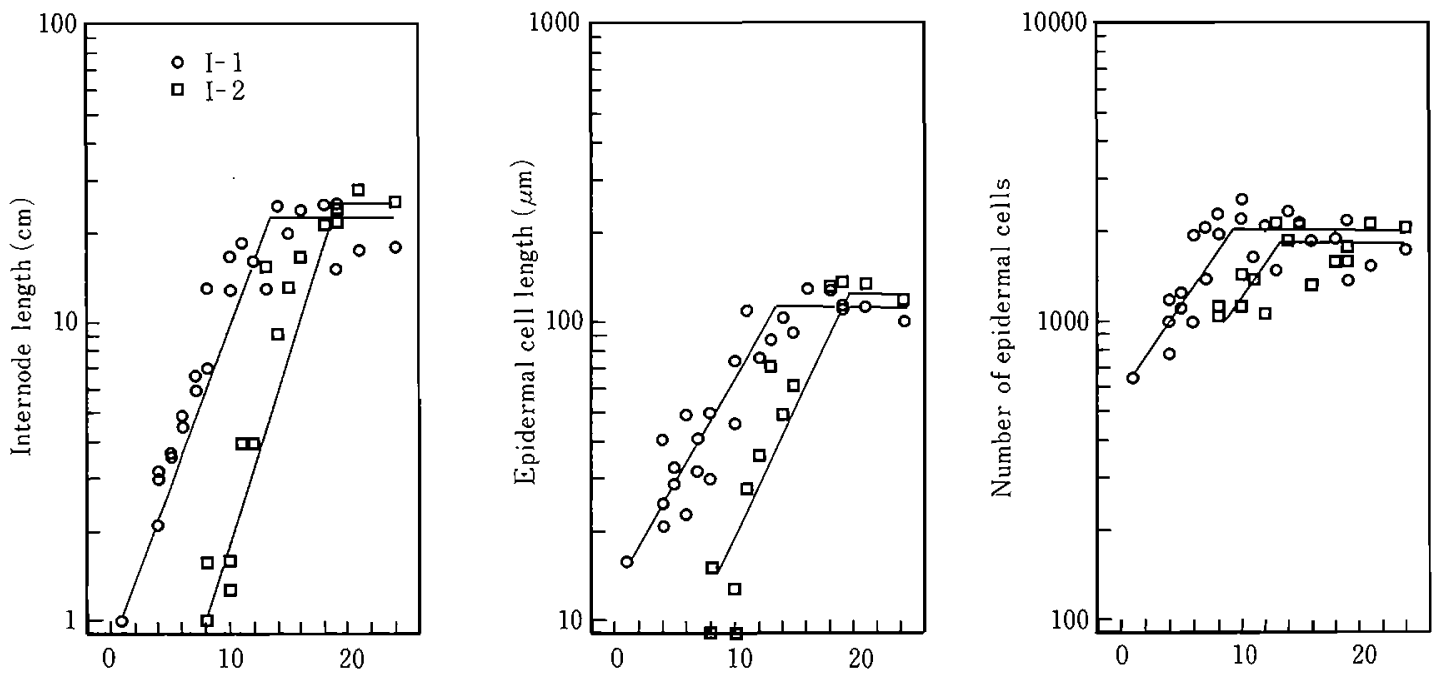

Days in the growth chamber

Fig. 3. Growth curves of the internode and internodal cell and the frequency of internodal cells of strawberry runners grown under $20^{\circ} \mathrm{C}$ and natural photoperiod. 


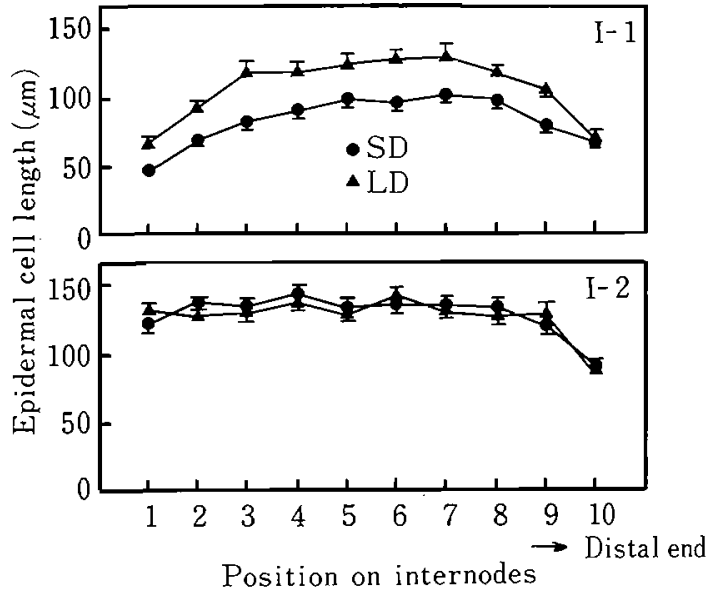

Fig. 4. The relationship between internodal cell length and their location on the runner as influenced by photoperiod. SD =9-hr day; $L D=16$-hr day. Each in ternode was divided into 10 segments of equal length. Each segment was designated as 1, 2, 3, etc. from the proximal end.

Table 1. Comparison of the internode length, epidermal cell length, and number of epidermal cells of strawberry runners exposed to a 9 -hr or a 16 -hr daylength.

\begin{tabular}{|c|c|c|c|}
\hline $\begin{array}{l}\text { Daylength } \\
\text { (hours) }\end{array}$ & $\begin{array}{l}\text { Internode } \\
\text { length } \\
(\mathrm{cm})\end{array}$ & $\begin{array}{l}\text { Epidermal } \\
\text { cell length } \\
(\mu \mathrm{m})\end{array}$ & $\begin{array}{l}\text { Number of } \\
\text { epidermal } \\
\text { cells }^{2}\end{array}$ \\
\hline \multicolumn{4}{|l|}{$I-1$} \\
\hline 9 & 13.7 & 77.7 & 1733 \\
\hline 16 & 17.7 & 100.4 & 1771 \\
\hline Significance & $* *$ & $* *$ & NS \\
\hline Increase $(\%)^{y}$ & 29.2 & 28.2 & 2.2 \\
\hline \multicolumn{4}{|l|}{$\mathrm{I}-2$} \\
\hline 9 & 16.2 & 125.5 & 1289 \\
\hline 16 & 18.5 & 125.2 & 1482 \\
\hline Significance & $*$ & NS & * \\
\hline Increase $(\%)^{y}$ & 14.2 & -0.2 & 15.0 \\
\hline \multicolumn{4}{|c|}{$\begin{array}{l}\text { Data were obtained from internode length divided by } \\
\text { epidermal cell length. }\end{array}$} \\
\hline \multicolumn{4}{|c|}{$\begin{array}{l}\text { Values represent the percentage of the increase under a } \\
16 \cdot \text { hr over a } 9 \cdot \mathrm{hr} \text { daylength. }\end{array}$} \\
\hline $\begin{array}{l}\text { NS. Nonsignific } \\
0.05 \text {, or } 0 .\end{array}$ & $* *^{*} *$ & significance o & f $F$ at $P \leqq$ \\
\hline
\end{tabular}

petiole lengths of L10 and L11 under LD are attributed to the longer cell lengths, 57.4 and $65.6 \%$ and the greater number of cells per petiole, 22.5 and $22.4 \%$, respectively. Note that the percentage of increase in the petiolar cell length is still larger than the percentage increase of petiolar
Table 2. Comparison of the petiole length, epidermal cell length, and number of epidermal cells of strawberry leaves exposed to a $9 \cdot \mathrm{hr}$ or a $16 \cdot \mathrm{hr}$ daylength.

\begin{tabular}{|c|c|c|c|}
\hline $\begin{array}{l}\text { Daylength } \\
\text { (hours) }\end{array}$ & $\begin{array}{l}\text { Petiole } \\
\text { length } \\
(\mathrm{cm})\end{array}$ & $\begin{array}{l}\text { Epidermal } \\
\text { cell length } \\
\quad(\mu \mathrm{m})\end{array}$ & $\begin{array}{l}\text { Number of } \\
\text { epidermal } \\
\text { cells }^{2}\end{array}$ \\
\hline \multicolumn{4}{|l|}{$\mathrm{L} 9^{y}$} \\
\hline 9 & 9.8 & 11.6 & 845 \\
\hline 16 & 14.7 & 17.8 & 846 \\
\hline Significance & $* *$ & $* *$ & NS \\
\hline Increase $(\%)^{x}$ & 50.0 & 53.4 & 0.1 \\
\hline \multicolumn{4}{|l|}{ L 10} \\
\hline 9 & 9.7 & 10.8 & 915 \\
\hline 16 & 18.8 & 17.0 & 1121 \\
\hline Significance & $* * *$ & $* *$ & $*$ \\
\hline Increase (\%) & 93.8 & 57.4 & 22.5 \\
\hline \multicolumn{4}{|l|}{ L 11} \\
\hline 9 & 9.2 & 9.0 & 1017 \\
\hline 16 & 18.3 & 14.9 & 1245 \\
\hline Significance & $* * *$ & $* *$ & $*$ \\
\hline Increase $(\%)$ & 98.9 & 65.6 & 22.4 \\
\hline
\end{tabular}

$z$ Data were obtained from petiole length divided by epidermal cell length.

$y$ Leaves were designated as L 1, L 2, L 3, etc. from the proximal end.

* Values represent the percentage of the increase under a 16-hr over a $9 \cdot \mathrm{hr}$ daylength.

NS , Nonsignificance; ${ }^{*}, * *, * * *$, significance of $\mathrm{F}$ at $P \leqq$ $0.05,0.01$, or 0.001 , respectively.

cells (Table 2).

\section{Discussion}

The elongation patterns of each internode were represented by a single sigmoid curve (Fig. 2) as indicated previously (Nishizawa and Hori, 1993). Guttridge and Thompson (1963) suggested that the number of petiolar cells in strawberry plants was mostly determined prior to the leaf emergence, and the rapid elongation after the emergence was mainly caused by the enlargement of the cells. However, this study showed that the early stage of exponential elongation of the internodes after the emergence was attributed to the increase in both the length and number of internodal cells. Similar obserbations on stem elongation of some herbaceous plants have been noted (Fisher and French, 1976; Maksymowych et al., 1984). The latter half of the exponential elongation was clear ly caused by the increase in the internodal cell length and not the number of internodal cells (Fig. 
3).

In both $\mathrm{I}-1$ and $\mathrm{I}-2$, the internode length was longer under $\mathrm{LD}$ than $\mathrm{SD}$ (Table 1). The difference in the internode length of $\mathrm{I}-1$ as influenced by the different photoperiods was mainly caused by the difference in the internodal cell length. Conversely, the difference in the internode length of $\mathrm{I}^{-} 2$ was due entirely to the difference in the number of internodal cells (Fig. 4 and Table 1). This variation is attributed to the different durations of cell division in each internode under a photoperiodic treatment. In $I-1$, the increase in the number of internodal cells ceased approximately 5 days earlier than that of I-2 (Fig. 3). Therefore, I-1 was in capable of increasing the number of internodal cell under LD.

This was also true for the petioles. When the elongation of runners started in the growth chamber, both $\mathrm{L} 10$ and L11 had not yet emerged. The difference in the petiole length of L9 as influenced by the different photoperiods was attributed to the difference in each individual petiolar cell length. On the other hand, the difference in the internode length of L10 and L11 was attributed to the difference in both the length and number of petiolar cells (Table 2). Thus, there was a similarity between petioles and runners of strawberry plants with respect to photoperiodism. The present study showed that the duration of cell division under a photoperiodic treatment was important in determining the ultimate number of internodal cells.

\section{Acknowledgement}

The author wishes to thank Professor R. Sakiyama of the University of Tokyo for his helpful comments. He is also grateful to Mr. T. Satoh,
Mr. T. Sasaki, and Mr. H. Kikuchi of the Prefectural Agricultural Research Center of Miyagi for supplying the samples.

\section{Literature Cited}

Fisher, J. B. and J. C. French. 1976. The occurrence of intercalary and uninterrupted meristems in the internodes of tropical monocotyledons. Amer. J. Bot. $63: 510-525$.

Garrison, R. 1973. The growth and development of internodes in Helianthus. Bot. Gaz. 134:246-255.

Gosselink, J. G. and C. R. Smith. 1967. Vegetative growth responses of strawberry plants to differing photoperiods. Hort. Res. $7: 24-33$.

Guttridge, C. G. 1970. Interaction of photoperiod, chilling and exogenous gibberellic acid on growth of strawberry petioles. Ann. Bot. $34: 349-364$.

Guttridge, C. G. and P. A. Thompson. 1963. The effect of daylength and gibberellic acid on cell length and number in strawberry petioles. Physiol. Plant. $16: 604-614$.

Maksymowych, R., C. Elsner, and A. B. Maksymowych. 1984. Internode elongation in Xanthium plants treated with gibberellic acid presented in terms of relative elemental rates. Amer. J. Bot. 71 : 239-244.

Nishizawa, T. 1990. Effects of daylength on cell length and cell number in strawberry petioles. J. Japan. Soc. Hort. Sci. 59 : 533-538. (In Japanese with English summary).

Nishizawa, T. 1992. The length and number of epidermal cells in petioles of strawberry plants as affected by photoperiod and temperature during vegetative and resting periods. J. Japan. Soc. Hort. Sci. $61: 559-564$.

Nishizawa, T. and Y. Hori. 1993. Elongation of strawberry runners in relation to length and number of cells. Tohoku J. Agr. Res. $43:$ 87-93. 
日長がイチゴのランナーの表皮細胞長と表皮細胞数におよぼす影響

\section{西沢 隆}

東京大学農学部 113 文京区弥生 1-1-1

\section{摘 要}

一季成り性イチゴ品種“ダナー’を供試し，ランナー が伸長生長する際の表皮細胞長と表皮細胞数の变化に ついて調べた.

1. ランナーは, 基部の節間 (I-1) の伸長生長速度 が最も早くなったときに先端部の節間（I-2）が指数 的に伸長し始めた。

2. 各節間の伸長はシングルシグモイド曲線を描い た. I-2の細胞分裂期間は, I-1 よりも約 5 日間長く 続いた。

3. I-1，I-2 とも，9 時間日長に比べ 16 時間日長下
で伸長したほうが長くなった。この増加は，1-1では 表皮細胞長が長くなったことによるものであった。一 方，I-2では表皮細胞数が増えたことによるものであ った。旦長がイチゴのランナーの表皮細胞長と表皮細 胞数の变化におよぼす影響が $\mathrm{I}-1$ と I-2 とで異なるの は，日長処理を開始した時点で両者の発育ステージに 違いがあったことによるものと考えられる。

4. 表皮細胞長と表皮細胞数の変化におよぼす日長 の影睤には，ランナーと葉唡との間で類似性が認めら れた。 